\title{
PENINGKATAN AKTIVITAS DAN KEMAMPUAN MENULIS SURAT LAMARAN PEKERJAAN MELALUI METODE SIBOMBER BERBANTUAN KUIS INTERAKTIF PADA PESERTA DIDIK KELAS I-4 SMA NEGERI 3 MALANG
}

\author{
Binti Ngafifatul Maidah ${ }^{*}$, Sugiarti², Basuki Agus Priyana Putra ${ }^{3}$. \\ ${ }^{1,2}$ Program Studi Pendidikan Profesi Guru, Universitas Muhammadiyah Malang, Indonesia \\ ${ }^{3}$ SMA Negeri 3 Malang, Indonesia \\ Email: binti_afifah@yahoo.com \\ *Corresponden Author
}

\begin{abstract}
ABSTRAK
Menulis surat lamaran pekerjaan penting bagi siswa SMA. Hal ini terkait dengan kondisi yang ada banyak peserta didik yang mengalami kesulitaan dalam menulis surat lamaran. Penelitian ini bertujuan untuk mendeskripsikan peningkatan aktivitas dan kemampuan menulis surat lamaran pekerjaan melalui metode SIBOMBER berbantuan kuis interaktif pada peserta didik kelas I-4 SMA Negeri 3 Malang. Penelitian Tindakan Kelas ini terdiri dari dua siklus dengan indikator ketuntasan klasikal $80 \%$. Subjek penelitian ini adalah peserta didik kelas I-4 SMAN 3 Malang sejumlah 20 peserta didik. Hasil penelitian ini menunjukkan bahwa (1) penerapan metode SIBOMBER berbantuan kuis interaktif dalam pembelajaran menulis surat lamaran pekerjaan mengalami peningkatan. Pada siklus I diperoleh rata-rata keseluruhan aktivitas peserta didik sebesar $72,61 \%$ menjadi $86,9 \%$ pada siklus II. Hasil peningkatan yang diperoleh mencapai 14,29\%. (2) Aktivitas peserta didik berdasarkan rata-rata keseluruhan aktivitas belajar yang muncul sesuai indikator mengalami peningkatan yaitu pada siklus I sebesar $66,14 \%$ menjadi $81,49 \%$ pada siklus II. Hasil penelitian menunjukkan bahwa terjadi peningkatan aktivitas belajar sebesar $15,35 \%$. (3) Peningkatan kemampuan menulis surat lamaran pekerjaan ditunjukkan dengan rata-rata nilai pada siklus I sebesar 77 menjadi 87,8 pada siklus II. Hasil peningkatan yang diperoleh mencapai 10,8. Hasil belajar klasikal pada siklus I sebesar $70 \%$ menjadi $100 \%$ pada siklus II sehingga meningkat sebesar $30 \%$.
\end{abstract}

Kata Kunci: Metode SIBOMBER; Kuis Interaktif; Menulis Surat Lamaran Pekerjaan; Aktivitas Belajar.

\begin{abstract}
Job application letters writing is an important subject for the High School students. This subject is parallel to the difficulty faced by the students in job application letters writing. This research aimed to describe the increase in activity and ability in job application letters writing through the SIBOMBER method assisted by interactive quizzes on students of class I-4 Malang State High School 3 (SMAN 3). This Classroom Action Research consisted of two cycles with $80 \%$ classical completeness indicators. The subjects of this research were $11^{\text {th }}$ grade students of SMAN 3 Malang in a number of 20 students. The results of this research indicate that (1) the implementation of the SIBOMBER method assisted by interactive quizzes in learning of job application letters writing has increased result. In the first cycle, the average overall activity of educators was scored $72.61 \%$ to $86.9 \%$ in cycle II. The results of the improvement reached $14.29 \%$. (2) Activity of students based on the average overall learning activities that appear according to the indicator has increased, namely in the first cycle score of $66.14 \%$ to $81.49 \%$ in the second cycle. The results showed that an increase in learning activities reached $15.35 \%$. (3) Increasing the ability to write job application letters is indicated by the average value in the first cycle score of 77 to 87.8 in the second cycle. The increase in improvement reached 10.8. Classical learning results in the first cycle score of $70 \%$ to $100 \%$ in the second cycle with $30 \%$ improvement
\end{abstract}

Keywords: SIBOMBER Method; Interactive Quiz; Writing Job Application Letters; Learning Activities 

Pekerjaan Melalui Metode Sibomber Berbantuan Kuis Interaktif Pada Peserta Didik Kelas I-4 SMA Negeri 3 Malang. JINoP (Jurnal Inovasi Pembelajaran), 6(1). doi:https://doi.org/10.22219/jinop.v6i1.8011

\section{PENDAHULUAN}

Pembelajaran bahasa memegang peranan penting dalam mewadahi kreativitas peserta didik. Pembelajaran bahasa diharapkan dapat membantu peserta didik dalam mengeksplorasi, mengungkapkan, dan menuangkan ide, gagasan, dan perasaan baik secara lisan ataupun tulisan. Dalam konteks ini, penguasaan bahasa yang baik tentu dapat menunjang olah pikiran, rasa, dan karsa peserta didik dalam menumbuhkan kreativitasnya. Oleh karena itu, pembelajaran bahasa diarahkan untuk meningkatkan keterampilan berbahasa seperti menyimak, membaca, berbicara, dan menulis pada peserta didik.

Keterampilan menulis merupakan keterampilan berbahasa yang berpotensi menumbuhkan kreativitas peserta didik. Peserta didik dapat mengembangkan bakat untuk berekspresi secara kreatif melalui pembelajaran menulis (Nuryani, 2016). Secara akademis, kegiatan memproduksi tulisan yang baik perlu dibekali dengan kemampuan pengetahuan dan keterampilan yang baik pula. Hal itu terkait dengan hasil tulisan yang tidak sekadar berwujud penuangan ide atau gagasan melainkan terdapat tata kebahasaan yang penting untuk diperhatikan. Menulis berarti kemampuan menggunakan kaidah kebahasaan untuk mengungkapkan gagasan atau pesan secara tertulis (Syarif, 2009). Hal ini mengisyaratkan bahwa peserta didik diharapkan mampu menguasai pengetahuan tentang teks yang akan diproduksi seperti struktur teks, kebahasaan, dan terampil dalam mencipta.

Distribusi kompetensi dasar di SMA Negeri 3 Malang menunjukkan bahwa salah satu aspek keterampilan menulis pada semester 4 adalah menulis surat lamaran pekerjaan. Aspek menulis tersebut terdapat pada KD 3.2 Mengidentifikasi unsur kebahasaan surat lamaran pekerjaan; 4.2 Menyusun surat lamaran pekerjaan dengan memerhatikan isi, sistematika, dan kebahasaan (Kemendikbud, 2016a).

Kemendikbud, (2016b) menetapkan indikator tercapainya tujuan pembelajaran dalam kurikulum 2013 ditandai dengan penguasaan kompetensi pengetahuan dan keterampilan. Kompetensi sikap peserta didik dalam proses pembelajaran juga menjadi bahan pertimbangan tercapainya tujuan pembelajaran. Dalam konteks menulis surat lamaran pekerjaan, peserta didik diharapkan mampu menguasai unsur-unsur pokok surat lamaran pekerjaan seperti isi, sistematika, kebahasaan, hal-hal yang perlu diperhatikan dalam menulis surat lamaran pekerjaan, dan prosedur penulisannya. Peserta didik juga diharapkan dapat menunjukkan sikap cermat, teliti, dan kreatif sehingga dapat menulis surat lamaran pekerjaan yang baik dan benar serta menarik.

Surat lamaran pekerjaan merupakan berkas yang ditulis individu untuk melamar pekerjaan disuatu instansi. Surat lamaran pekerjaan tergolong ke dalam surat resmi sehingga memiliki aturan tertentu dalam penulisannya seperti isi, sistematika, dan kebahasaannya. Surat lamaran pekerjaan juga termasuk surat penawaran yang ditujukan 
ke suatu lembaga (Suryaman, Maman., Suherli., 2018). Dengan demikian dapat dikatakan bahwa surat lamaran pekerjaan sebagai surat resmi bertujuan untuk menyampaikan penawaran kerja secara tertulis kepada intansi tertentu dengan memerhatikan isi, sistematika, dan kebahasaannya.

Pembelajaran menulis surat resmi sudah dibelajarkan sejak kelas V sekolah dasar. Pada jenjang sekolah menengah pertama kelas VII, peserta didik juga mempelajari kompetensi tersebut. Fenomena yang ada justru menunjukkan bahwa kemampuan peserta didik dalam menulis surat lamaran pekerjaan cukup rendah. Hal itu dapat dilihat dari hasil produksi surat lamaran pekerjaan yang masih terdapat banyak kesalahan dalam penulisannya. Misalnya penggunaan huruf kapital, kata baku, ejaan dan tanda baca (PUEBI), kalimat efektif, dan lain sebagainya. Adanya hal tersebut tentu menjadi perhatian pendidik untuk meningkatkan kemampuan peserta didik dalam praktik menulis surat lamaran pekerjaan.

Prinsip pembelajaran bahasa Indonesia dalam silabus mata pelajaran bahasa Indonesia SMA dijelaskan bahwa proses pembelajaran menekankan aktivitas peserta didik yang bermakna (Kemendikbud, 2016c). Aktivitas belajar yang bermakna melibatkan peserta didik secara aktif dalam proses pembelajaran. Peserta didik dapat menyerap informasi atau konsep secara komprehensif sehingga meningkatkan hasil belajarnya. Berkenaan dengan hal tersebut, pendidik sebagai motivator dan fasilitator diharapkan mampu menciptakan suasana belajar yang menyenangkan dan melibatkan peserta didik secara aktif. Pendidik juga harus mampu memilih metode atau media yang tepat untuk menggerakkan aktivitas dan kreativitas peserta didik dalam pembelajaran sehingga peserta didik lebih antusias mengikuti pelajaran, aktif bertanya, dan berani mengemukakan ide atau gagasan baik secara lisan maupun tulisan.

Berdasarkan hasil observasi dan wawancara pada kegiatan belajar mengajar Bahasa Indonesia di kelas I-4 (IPS) SMA Negeri 3 Malang ditemukan beberapa permasalahan yang berkaitan dengan aktivitas dan hasil belajar peserta didik pada keterampilan menulis yaitu: (1) antusias peserta didik dalam mengikuti pembelajaran kurang ditunjukkan dengan adanya kegiatan tidak relevan yang dilakukan saat proses pembelajaran seperti bermain gawai, mengerjakan tugas selain bahasa Indonesia, mengobrol dengan teman sebangkunya, dan lain sebagainya; (2) keaktifan peserta didik dalam bertanya kepada pendidik, menjawab pertanyaan, dan menanggapi permasalahan atau presentasi masih rendah dibuktikan dengan peserta didik yang aktif cenderung sama; (3) kaidah kebahasaan menulis surat lamaran yang sesuai PUEBI (Pedoman Umum Ejaan Bahasa Indonesia) merupakan materi yang cukup sulit dipahami oleh peserta didik sehingga masih terdapat beberapa kesalahan penggunaan tanda baca, ejaan, penggunaan huruf kapital, kata baku, dan penyingkatan kata dalam hasil tulisannya; (4) model atau metode yang diterapkan dalam pembelajaran kurang bervariasi. Sejauh ini, pendidik menggunakan model atau metode pembelajaran peta konsep dan presentasi. Penggunaan metode tersebut cukup bagus untuk pemahaman konsep awal peserta didik. Akan tetapi, berdasarkan observasi yang dilakukan, peserta didik cenderung individualis dalam belajar. Peserta didik yang memiliki kemampuan kurang dan sedang cenderung pasif dalam mengemukakan pendapat ataupun menanggai presentasi. Akibatnya, aktivitas peserta didik yang kurang maskimal berpengaruh terhadap hasil yang kurang maksimal

Binti Ngafifatul Maidah, Sugiarti, Basuki Agus Priyana Putra, Peningkatan Aktivitas Dan Kemampuan Menulis Surat Lamaran Pekerjaan Melalui Metode Sibomber Berbantuan Kuis Interaktif pada Peserta Didik Kelas I-4 SMA Negeri 3 Malang 
pula. Oleh karena itu, diperlukan desain pembelajaran yang menarik dan mampu melibatkan peserta didik secara individu maupun kelompok heterogen.

Model pembelajaran Bestek-Kreatif adalah model pembelajaran berdasarkan pada pendekatan kreatif. Model pembelajaran tersebut mempunyai beberapa tipe atau metode yang salah satunya adalah SIBOMBER. Sukatman, 2013:88 menyatakan bahwa model Bestek Kreatif mendorong belajar kreatif, cermat, dan tajam pikiran. Peserta didik didorong untuk mengoptimalkan dan menuntaskan permasalahan yang belum dikuasai baik secara mandiri maupun dengan bantuan teman sebaya atau pendidik.

Model pembelajaran Bestek-Kreatif tipe SIBOMBER bertujuan mengembangkan kemampuan peserta didik dalam menyerap dan menerima pengetahuan secara individu ataupun dari teman sebaya. Tujuan tersebut berkonstribusi pada kemampuan peserta didik dalam memecahkan persoalan baik ilmu pengetahuan atau keterampilan secara kreatif. Pada proses pembelajaran metode SIBOMBER terdapat lima tahapan atau fase (Sukatman, 2013:90-91) yaitu sebagai berikut.

1) $\mathrm{Si}$ (siapkan rencana belajar)

Pada tahap ini dilakukan kegiatan pembentukan kelompok, eksplorasi (menggali), dan pemaparan masalah konseptual dan kontekstual. Kegiatan ini berfungsi untuk membangun interaksi belajar peserta didik dan membantu peserta didik dalam menggali permasalahan yang diajukan.

2) $B$ (belajar terbimbing)

Peserta didik secara berkelompok berdiskusi untuk memecahkan permasalahan (kuis) dan memaparkannya dengan tutor sebaya masing-masing. Kegiatan ini bertujuan untuk menumbuhkan sikap kolaboratif atau kerjasama dalam kelompok.

3) $O$ (optimal-tuntaskan)

Pada tahap ini peserta didik mengkaji dan memperdalam materi tentang surat lamaran pekerjaan yang belum dipahami dengan dibimbing tutor sebaya. Melalui kegiatan ini, setiap peserta didik dalam kelompok diharapkan dapat memecahkan permasalahan yang belum dipahami sampai tuntas.

4) $M$ (mandiri)

Pada tahap ini, peserta didik diarahkan untuk memperdalam materi sesuai sasaran belajar dan berlatih memecahkan masalah secara mandiri. Dalam hal ini, peserta didik dapat mencari informasi atau referensi dari berbagai sumber.

5) Ber (berlatih, evaluasi diri, dan refleksi)

Pendidik mengadakan evaluasi untuk mengukur keberhasilan belajar yang dibimbing tutor sebaya secara individu. Setelah itu, pendidik merefleksi kegiatan dan hasil belajar sebagai perencanaan remidi atau pengayaan untuk mencapai tujuan belajar secara optimal.

Penggunaan metode SIBOMBER dalam penelitian tindakan kelas dipadukan dengan media pembelajaran berbasis teknologi. Media ini berupa kuis interaktif yang dirancang melalui power point. Adiwisastra (2015) mengemukakan kuis interaktif merupakan media pembelajaran yang didesain dalam bentuk game berisi pertanyaan atau latihan soal dengan aturan tertentu untuk meningkatkan hasil belajar dan minat belajar peserta didik. Senada dengan pendapat tersebut, Kartikasari (2010) menyatakan penggunaan media pembelajaran interaktif dapat memotivasi peserta didik meningkatkan 
pengetahuan dan ketarampilannya. Berdasarkan penelusuran penelitian terdahulu tentang surat lamaran pekerjaan.

Penelitian sejenis yang telah dilakukan oleh Manulu (2018) tentang Peningkatan Kemampuan Menulis Surat Lamaran Pekerjaan Menggunakan Metode Pembelajaran STAD bagi Siswa Kelas XII IPA SMA Negeri 14 Medan Tahun Ajaran 2018-2019 diperoleh kesimpulan bahwa siswa bersemangat ketika menulis lamaran perkerjaan. Dari lembar siklus 1 dan 2 dapat disimpulkan bahwa terjadi perubahan perilaku siswa kea rah yang lebih baik. Demikian pula, penelitian Lukman (2018) Peningkatan Hasil Belajar Menulis Surat Lamaran Pekerjaan dengan Menggunakan Media Power Point bahwa ketuntasan belajar perorangan subjek penelitian dari kondisi awal sebesar $20 \%$ ke akhir siklus I yang mencapai 55\% berarti mengalami kenaikan 35\%. Dari siklus I ke akhir siklus II juga ada peningkatan ketuntasan belajar perorangan, yaitu dari $69 \%$ pada siklus I menjadi 88\% di akhir siklus II.

Perbedaan penelitian ini dengan penelitian sebelumnya terletak pada metode pembelajaran STAD dan power point. Penelitian ini menggunakan metode Simbober yang dipadu dengan kuis interaktif yang disusun dalam bentuk pertanyaan-pertanyaan tentang isi, sistematika, dan kebahasaan surat lamaran pekerjaan. Kuis tersebut diharapkan dapat merangsang minat belajar peserta didik dan memudahkannya dalam menyerap atau memahami materi surat lamaran pekerjaan. Keberadaan metode SIBOMBER juga memberi variasi dalam meningkatkan keterampilan menulis yang pada umumnya

Berdasarkan uraian di atas, maka tujuan penelitian ini adalah untuk meningkatkan aktivitas dan kemampuan menulis surat lamaran pekerjaan melalui metode SIBOMBER berbantuan kuis interaktif pada peserta didik kelas I-4 SMA Negeri 3 Malang.

\section{METODE}

Jenis penelitian ini adalah penelitian tindakan kelas (PTK). Pelaksanaan penelitian tindakan kelas digunakan untuk mengatasi permasalahan dalam pembelajaran surat lamaran pekerjaan dengan menggunakan metode SIBOMBER berbantuan kuis interaktif. Dalam pelaksanaannya, peneliti berperan merencanakan tindakan, melaksanakan tindakan, observasi secara langsung untuk mengumpulkan data, dan menganalisis data. Selain itu, kehadiran guru pengampu bahasa Indonesia atau teman sebaya sebagai observer membantu peneliti dalam memberikan masukan dan saran terhadap keterlaksanaan proses pembelajaran.

Subjek penelitian tindakan kelas ini adalah peserta didik kelas I-4 (IPS) SMA Negeri 3 Malang. Jumlah peserta didik yaitu 20 orang yang terdiri dari 6 peserta didik laki-laki dan 14 peserta didik perempuan. Desain PTK di kelas tersebut akan dilaksanakan dalam dua siklus dengan tahapan yaitu perencanaan, pelaksanaan, observasi, dan refleksi.

Teknik pengumpulan data dalam penelitian ini adalah observasi, tes, dan dokumentasi. Data yang terkumpul akan dianalisis secara deskriptif kualitatif dan kuantitatif. Analisis data dalam penelitian ini dilakukan setiap kali pelaksanaan tindakan.

1. Analisis Aktivitas Pendidik

Hasil aktivitas pendidik yang dianalisis diperoleh dari observasi yang dilakukan oleh observer selama pembelajaran berlangsung. Melalui skor yang diperoleh dapat

\footnotetext{
Binti Ngafifatul Maidah, Sugiarti, Basuki Agus Priyana Putra, Peningkatan Aktivitas Dan Kemampuan Menulis Surat Lamaran Pekerjaan Melalui Metode Sibomber Berbantuan Kuis Interaktif pada Peserta Didik Kelas I-4 SMA Negeri 3 Malang
} 
ditentukan peningkatan aktivitas pendidik dalam menggunakan metode SIBOMBER berbantuan kuis interaktif pada pembelajaran menulis surat lamaran pekerjaan.

Nilai $=\frac{\sum \text { skor yang dicapai }}{\sum \text { skor maksimal }} \times 100 \%$

Nilai ketercapaian aktivitas pendidik dalam menggunakan metode SIBOMBER berbantuan kuis interaktif pada pembelajaran menulis surat lamaran pekerjaan dikategorikan menjadi 4 taraf keberhasilan seperti yang tertera dalam tabel 1, berikut:

Tabel 1 Kriteria Aktivitas Pendidik

\begin{tabular}{cc}
\hline Kriteria & Nilai \\
\hline A (Sangat Baik) & $85-100$ \\
\hline B (Baik) & $70-84$ \\
\hline C (Cukup) & $55-69$ \\
\hline D (Kurang) & $<55$ \\
\hline
\end{tabular}

2. Analisis Aktivitas Peserta Didik

Hasil aktivitas peserta didik yang dianalisis diperoleh dari observasi selama pembelajaran berlangsung. Peningkatan aktivitas ditentukan melalui perolehan skor peserta didik.

Nilai $=\frac{\sum \text { skor yang dicapai }}{\sum \text { skor maksimal }} \times 100 \%$

Aktivitas belajar peserta didik yang telah dihitung akan ditentukan kriteria ketuntasannya. Kriteria yang digunakan sebagai pedoman yaitu sesuai pada tabel 2 , berikut.

Tabel 2 Kriteria Aktivitas Peserta Didik

\begin{tabular}{cc}
\hline Kriteria & Nilai \\
\hline A (Sangat Baik) & $85-100$ \\
\hline B (Baik) & $70-84$ \\
\hline C (Cukup) & $55-69$ \\
\hline D (Kurang) & $<55$ \\
\hline
\end{tabular}

3. Analisis Hasil Belajar Peserta Didik

Hasil belajar peserta didik yang dianalisis diperoleh dari nilai tes menulis surat lamaran pekerjaan setelah penerapan metode SIBOMBER berbantuan kuis interaktif pada siklus I dan siklus II. Analisis hasil belajar peserta didik diawali dengan penskoran nilai, mencari rata-rata nilai, dan ketercapaian KKM. Perumusan nilai yang dijadikan pedoman dalam penelitian ini adalah sebagai berikut. 
Nilai rata-rata $=\frac{N n}{N}$

Perumusan ketuntasan klasikal (\%)

Jumlah peserta didik tuntas KKM

Jumlah seluruh peserta didik

Keterangan:

$\mathrm{Nn}=$ Jumlah nilai seluruh peserta didik

$\mathrm{n} \quad=$ Jumlah peserta didik

Indikator keberhasilan dalam penelitian ini adalah meningkatnya aktivitas pendidik, aktivitas belajar peserta didik, dan kemampuan menulis surat lamaran peserta didik pada siklus I dan siklus II. Ketuntasan belajar secara klasikal untuk hasil belajar menulis surat lamaran pekerjaan dilihat adanya $80 \%$ peserta didik tuntas KKM. Nilai KKM pelajaran bahasa Indonesia di SMA Negeri 3 Malang adalah 70.

\section{HASIL DAN PEMBAHASAN}

Hasil dan pembahasan pada artikel ini berisi pemaparan analisis data yaitu (1) penerapan metode SIBOMBER berbantuan kuis interaktif untuk meningkatkan aktivitas dan kemampuan menulis surat lamaran pada peserta didik kelas I-4 SMA Negeri 3 Malang, dan (2) peningkatan aktivitas dan kemampuan menulis surat lamaran pekerjaan dengan menggunakan metode SIBOMBER berbantuan kuis interaktif pada peserta didik kelas I-4 SMA Negeri 3 Malang. Berikut disajikan hasil dan pembahasan penelitian.

\section{Penerapan Metode SIBOMBER Berbantuan Kuis Interaktif untuk Meningkatkan Aktivitas dan Kemampuan Menulis Surat Lamaran Pekerjaan pada Peserta Didik Kelas I-4 SMA Negeri 3 Malang}

Penelitian tindakan kelas yang dilaksanakan di kelas I-4 SMA Negeri 3 Malang terlaksana dalam dua siklus. Setiap siklus berlangsung selama dua kali pertemuan dengan alokasi waktu empat jam pelajaran (4x45 menit) persiklusnya. Tindakan yang dilaksanakan pada siklus I dan siklus II didasarkan pada Rencana Pelaksanan Pembelajaran (RPP) yang telah didesain berdasarkan metode pembelajaran SIBOMBER berbantuan kuis interaktif.

Proses pembelajaran pada siklus I dimulai dengan pembentukan kelompok. Peserta didik dibagi menjadi 5 kelompok dengan masing-masing kelompok berjumlah 4 peserta didik. Setiap kelompok memiliki satu tutor sebaya yang bertugas membimbing atau membantu temannya untuk mempelajari materi surat lamaran pekerjaan. Pembagian kelompok tersebut dibentuk pendidik secara heterogen berdasarkan tingkat kemampuan dan jenis kelamin peserta didik. Tujuannya agar peserta didik dapat saling bekerjasama menyelesaikan permasalahan, bertukar pendapat, dan berbagi ide dengan teman sekelompoknya.

\footnotetext{
Binti Ngafifatul Maidah, Sugiarti, Basuki Agus Priyana Putra, Peningkatan Aktivitas Dan Kemampuan Menulis Surat Lamaran Pekerjaan Melalui Metode Sibomber Berbantuan Kuis Interaktif pada Peserta Didik Kelas I-4 SMA Negeri 3 Malang
} 
Kegiatan selanjutnya adalah peserta didik bermain kuis interaktif tentang isi, sistematika, dan kebahasaan surat lamaran pekerjaan yang disajikan melalui media power point. Kelompok yang cepat dan tepat dalam menjawab akan mendapatkan 10 poin. Setelah itu, pendidik mengarahkan masing-masing kelompok untuk belajar terbimbing dengan tutor sebaya. Peserta didik bersama tutor sebaya memperdalam materi tentang isi, sistematika, kebahasaan, hal-hal yang harus diperhatikan dalam menulis surat lamaran pekerjaan, dan prosedur menulis surat secara tuntas. Selanjutnya, peserta didik secara mandiri diperbolehkan untuk mencari referensi lain dari berbagai sumber seperti buku dan internet untuk memperdalam pemahamannya.

Langkah berikutnya, pendidik mengadakan evaluasi atau tes yaitu membuat rancangan surat lamaran pekerjaan berdasarkan ilustrasi pekerjaan yang dipilih secara mandiri. Beberapa peserta didik mempresentasikan hasil pekerjaannya di depan kelas dan ditanggapi oleh peserta didik lainnya. Pendidik memberikan apresiasi terhadap kelompok terbaik dan peserta didik terbaik pada proses pembelajaran. Pendidik juga merefleksi kegiatan dan hasil pekerjaan peserta didik. Selanjutnya, pendidik memberikan penguatan karakter sosial dan materi agar peserta didik lebih bersemangat untuk menulis surat lamaran pekerjaan yang baik dan benar.

Hasil pengamatan observer dan refleksi terhadap aktivitas pendidik menunjukkan bahwa terdapat beberapa persoalan yang perlu diperbaiki diantaranya (1) ilustrasi lowongan pekerjaan yang digunakan untuk menulis surat lamaran pekerjaan terdapat petunjuk yang kurang jelas sehingga sulit dipahami, (2) sikap pendidik dengan peserta didik kurang luwes, dan (3) kondisi ruang dan jam pelajaran yang kurang efektif membuat pendidik kurang luwes dalam mengelola kelas, sehingga pencapaian kompetensi belum sesuai target. Berkenaan dengan hal tersebut, adapun perbaikan untuk proses pembelajaran pada siklus II antara lain. Pertama, pendidik menggunakan media iklan sebagai sumber untuk menulis surat lamaran pekerjaan. Kedua, pendidik mengoptimalkan dan mengelola waktu dengan baik sehingga pembelajaran dapat terlaksana secara efektif dan efisien.

Setelah dilakukan perbaikan pada siklus II, proses pembelajaran menulis surat lamaran pekerjaan melalui metode SIBOMBER berbantuan kuis interaktif pada peserta didik kelas I-4 terlaksana dengan baik. Menurut observer media dan metode pembelajaran yang digunakan sudah sesuai materi dan peserta didik bisa mengikuti pembelajaran secara baik. Pencapaian kompetensi menulis sudah terlaksana sesuai tujuan pembelajaran yang ditetapkan.

Kegiatan pembelajaran pada siklus II peserta didik diarahkan untuk kritis memperbaiki kesalahan isi, sistematika, dan kebahasaan pada rancangan surat lamaran yang dibuat. Hal itu bertujuan agar peserta didik mampu menulis surat lamaran yang baik dan benar dari segi isi, sistematika, dan kebahasaannya. Pada siklus II, pendidik memberikan kuis interaktif tentang perbaikan penulisan unsur-unsur isi surat lamaran pekerjaan yang benar untuk mengingatkan kembali materi yang telah dipelajari. Peserta didik diarahkan untuk membentuk kelompok sesuai formasi baru yang telah dibentuk oleh pendidik. Selanjutnya, pendidik membimbing langsung peserta didik untuk memahami kembali materi yang belum dikuasai. Pada proses ini peserta didik diberi kesempatan untuk bertanya tentang kesulitan yang belum dipahami kepada pendidik ataupun tutor sebaya. Pendidik memberikan evaluasi secara mandiri berupa kegiatan 
menulis surat lamaran pekerjaan berdasarkan rancangan yang telah dibuat dengan memerhatikan isi, sistematika, dan kebahasaannya.

Hasil kinerja pendidik dalam menerapkan metode SIBOMBER berbantuan kuis interaktif pada pembelajaran menulis surat lamaran pekerjaan di kelas I-4 SMA Negeri 3 Malang menunjukkan adanya peningkatan. Hal tersebut dapat diketahui melalui hasil observasi yang dilakukan oleh observer seperti pada tabel berikut.

Tabel 3 Perbandingan Hasil Observasi Aktivitas Pendidik pada Siklus I dan Siklus II

\begin{tabular}{|c|c|c|c|}
\hline \multirow[t]{2}{*}{ No. } & \multirow[t]{2}{*}{ Aspek yang dinilai } & \multicolumn{2}{|c|}{ Skor } \\
\hline & & Siklus I & Siklus II \\
\hline 1. & Penguasaan materi & 8 & 10 \\
\hline 2. & Sistematika penyajian & 9 & 11 \\
\hline 3. & Penerapan metode & 9 & 10 \\
\hline 4. & Penggunaan media & 8 & 11 \\
\hline 5. & Penampilan (performance) & 8 & 11 \\
\hline 6. & Pemberian motivasi & 10 & 10 \\
\hline 7. & Pengelolaan kelas & 9 & 10 \\
\hline & Jumlah & 61 & 73 \\
\hline & Persentase (\%) & $72.61 \%$ & $86.9 \%$ \\
\hline & Peningkatan (\%) & \multicolumn{2}{|c|}{$14.29 \%$} \\
\hline & Kriteria & Baik & Sangat baik \\
\hline
\end{tabular}

Berdasarkan tabel 3 dapat diketahui bahwa pada siklus I pendidik memeroleh jumlah skor 61 dengan persentase $72,61 \%$ termasuk dalam kategori baik. Sementara itu, pada siklus II jumlah skor yang diperoleh meningkat menjadi 73 dengan persentase $86,9 \%$ termasuk dalam kategori sangat baik. Dari perolehan aktivitas pendidik pada siklus I ke siklus II mengalami peningkatan sebesar 14.29\%. Hal tersebut menunjukkan bahwa perbaikan yang dilakukan pada siklus II mampu meningkatkan aktivitas pendidik pada setiap indikatornya.

\section{Peningkatan Aktivitas dan Kemampuan Menulis Surat Lamaran Pekerjaan melalui Metode SIBOMBER Berbantuan Kuis Interaktif pada Peserta Didik Kelas I-4 SMA Negeri 3 Malang}

Aktivitas belajar dan hasil belajar merupakan pedoman yang dijadikan untuk mengetahui ketuntasan capaian belajar peserta didik. Pada bagian ini akan dipaparkan tentang peningkatan aktivitas dan kemampuan menulis surat lamaran pekerjaan melalui metode SIBOMBER berbantuan kuis interaktif pada peserta didik kelas I-4 SMAN 3 Malang.

a) Peningkatan aktivitas peserta didik dalam pembelajaran menulis surat lamaran pekerjaan melalui metode SIBOMBER berbantuan kuis interaktif.

Aktivitas belajar termasuk dalam penilaian proses yang dijadikan bahan pertimbangan ketuntasan hasil belajar peserta didik. Hasil refleksi proses pembelajaran dari observer menunjukkan bahwa pada siklus I peserta didik cukup antusias memerhatikan penjelasan pendidik mengenai kegiatan pembelajaran yang akan dilaksanakan dan mengerjakan tugas menulis surat lamaran pekerjaan dengan cukup baik. Meskipun demikian, ada beberapa aktivitas yang belum mencolok dalam proses pembelajaran yaitu (1) peserta didik masih kurang aktif dan berani dalam menyampaikan

Binti Ngafifatul Maidah, Sugiarti, Basuki Agus Priyana Putra, Peningkatan Aktivitas Dan Kemampuan Menulis Surat Lamaran Pekerjaan Melalui Metode Sibomber Berbantuan Kuis Interaktif pada Peserta Didik Kelas I-4 SMA Negeri 3 Malang 
gagasan atau menjawab kuis interaktif, (2) beberapa peserta didik menunjukkan sikap kurang tertarik dengan media kuis interaktif yang digunakan pendidik, (3) beberapa kelompok masih belum kondusif saat belajar terbimbing dengan tutor sebaya, karena terdapat peserta didik yang tidak ikut berdiskusi dengan kelompoknya, (4) beberapa peserta didik dalam kelompok kurang memahami materi yang diberikan oleh tutor sebaya, dan (5) kondisi ruang dan jam pelajaran yang kurang efektif berpengaruh terhadap kondusifitas peserta didik dalam kelas. Beberapa hal tersebut mengindikasikan bahwa aktivitas belajar peserta didik pada siklus I berjalan kurang optimal sehingga perlu adanya perbaikan pada siklus II.

Upaya perbaikan yang dilakukan pendidik untuk mengatasi permasalahan pada siklus I antara lain. Pertama, pendidik memberikan kesempatan kepada semua peserta didik untuk ikut serta menjawab kuis interaktif. Kedua, pendidik memberikan apresiasi ungkapan positif kepada peserta didik setelah menjawab pertanyaan dengan benar. Ketiga, pendidik lebih maksimal dalam mengontrol dan membimbing peserta didik dalam kelompok untuk mengoptimalkan pemahaman tentang materi yang belum dikuasai. Keempat, pendidik merubah formasi kelompok untuk beberapa peserta didik yang kurang mampu dan memberikan bimbingan secara langsung. Setelah dilaksanakan perbaikan tersebut, pada siklus II aktivitas belajar peserta didik menunjukkan adanya peningkatan yang lebih baik. Peserta didik menunjukkan ketertarikan dengan media pembelajaran (kuis interaktif) sehingga peserta didik mulai aktif menjawab kuis interaktif dan berani menyampaikan gagasannya. Perhatian peserta didik sudah tertuju pada penjelasan materi yang disampaikan oleh pendidik ataupun tutor sebaya. Peserta didik yang sebelumnya belum ikut diskusi mulai serius mengikuti kegiatan diskusi. Peserta didik juga tampak bersungguh-sungguh mengerjakan tugas individu menulis surat lamaran pekerjaan dan mengumpulkannya secara tepat waktu. Berkenaan dengan hal tersebut, dapat dikatakan bahwa pada siklus II kegiatan belajar mengajar menggunakan metode SIBOMBER berbantuan kuis interaktif terlihat lebih efektif, efisien, dan kondusif. Berikut perbandingan beserta peningkatan aktivitas peserta didik pada siklus I dan siklus II dalam pembelajaran menulis surat lamaran pekerjaan melalui metode SIBOMBER berbantuan kuis interaktif.

Tabel 4 Perbandingan Aktivitas Belajar Peserta Didik pada Siklus I dan Siklus II

\begin{tabular}{clccc}
\multirow{2}{*}{ No. } & \multirow{2}{*}{ Aspek yang dinilai } & \multicolumn{2}{c}{ Ketercapaian } & Peningkatan (\%) \\
\cline { 3 - 4 } & & Siklus I (\%) & Siklus II (\%) & \\
\hline 1. & Perhatian & $73,75 \%$ & $87,5 \%$ & $13,75 \%$ \\
\hline 2. & Bertanya & $48,33 \%$ & $66,66 \%$ & $18,33 \%$ \\
\hline 3. & Berpendapat & $52 \%$ & $71,66 \%$ & $19,66 \%$ \\
\hline 4. & Penugasan & $81,66 \%$ & $95 \%$ & $13,34 \%$ \\
\hline 5. & Diskusi & $75 \%$ & $86,66 \%$ & $11,66 \%$ \\
\hline & Rata-rata & $66,14 \%$ & $81,49 \%$ & $15,35 \%$ \\
\hline
\end{tabular}

Berdasarkan tabel 4 dapat diketahui bahwa penerapan metode SIBOMBER berbantuan kuis interaktif dalam pembelajaran menulis surat lamaran pekerjaan mampu meningkatkan aktivitas belajar peserta didik. Aktivitas belajar peserta didik setiap aspeknya mengalami peningkatan dari siklus I ke siklus II. Aspek aktivitas peserta didik yang dimaksud yaitu perhatian, bertanya, berpendapat, penugasan, dan diskusi. 
Aspek perhatian menggambarkan aktivitas senang dengan media atau metode pembelajaran, memerhatikan atau fokus terhadap penjelasan guru atau teman, menunjukkan sikap tenang, dan antusias mengikuti proses pembelajaran. Persentase aspek perhatian pada siklus I sebesar $73,75 \%$ termasuk dalam kategori baik sedangkan pada siklus II meningkat menjadi $87,5 \%$ dengan kategori sangat baik. Hasil peningkatan persentase aspek perhatian yaitu sebesar $13,75 \%$.

Aspek bertanya menggambarkan aktivitas peserta didik dalam mengajukan pertanyaan kepada pendidik atau teman dan bertanya sesuai materi yang diberikan. Persentase aspek bertanya pada siklus I sebesar $48.33 \%$ termasuk dalam kategori kurang sedangkan pada siklus 2 meningkat menjadi $66.66 \%$ termasuk dalam kategori cukup. Hasil peningkatan persentase aspek bertanya yaitu sebesar 18,33\%.

Aspek berpendapat merupakan aktivitas peserta didik dalam menjawab kuis atau pertanyaan dari pendidik, menyampaikan gagasan dalam diskusi kelompok ataupun kelas, dan menanggapi presentasi teman. Pada siklus I peresentase yang diperoleh sebesar $52 \%$ termasuk dalam kategori kurang sedangkan pada siklus meningkat menjadi $71,66 \%$ termasuk dalam kategori baik. Hasil peningkatan persentase aspek berpendapat sebesar $19,66 \%$.

Aspek penugasan mencakup aktivitas peserta didik dalam mengerjakan tugas secara sungguh-sungguh, dapat bekerja secara mandiri ataupun kelompok, dan mengumpulkan tugas sesuai waktunya. Persentase aspek penugasan pada siklus I sebesar 81,66\% termasuk dalam kategori baik sedangkan pada siklus II meningkat menjadi 95\% termasuk dalam kategori sangat baik. Hasil peningkatan persentase aspek penugasan yaitu sebesar $13,34 \%$.

Aspek diskusi menggambarkan aktivitas peserta didik dalam mendengarkan pendapat teman, memberikan pendapat dalam kelompok, dan menjelaskan hasil diskusi dalam kelompok ataupun kelas. Pada siklus I persentase yang diperoleh sebesar $75 \%$ meningkat menjadi $86,66 \%$ pada siklus II dan termasuk dalam kategori baik. Hasil peningkatan persentase aspek diskusi sebesar $11,66 \%$.

Persentase rata-rata keseluruhan aktivitas belajar peserta didik pada siklus I sebesar $66,14 \%$ termasuk dalam kategori cukup. Sementara itu, pada siklus II meningkat menjadi 81,49 termasuk dalam kategori baik dengan peningkatan mencapai 15,35\%. Dengan demikian, dapat disimpulkan bahwa pembelajaran menulis surat lamaran pekerjaan melalui metode SIBOMBER berbantuan kuis interaktif mampu meningkatkan aktivitas belajar peserta didik yang meliputi perhatian, bertanya, berpendapat, penugasan, dan diskusi. Secara keseluruhan peserta didik menunjukkan peningkatan atau perubahan aktivitas belajar mulai dari yang sangat baik, baik, cukup, dan kurang. Aktivitas belajar tersebut dapat mendorong peserta didik untuk memeroleh hasil menulis surat lamaran pekerjaan yang baik pula.

b) Peningkatan kemampuan menulis surat lamaran pekerjaan dengan menggunakan metode SIBOMBER berbantuan kuis interaktif

Penelitian tindakan kelas dengan penerapan metode SIBOMBER berbantuan kuis interaktif dapat meningkatkan kemampuan menulis surat lamaran pekerjaan pada peserta didik kelas I-4 SMA Negeri 3 Malang. Hasil evaluasi kemampuan menulis surat lamaran pekerjaan menunjukkan bahwa perolehan rata-rata nilai peserta didik mengalami

Binti Ngafifatul Maidah, Sugiarti, Basuki Agus Priyana Putra, Peningkatan Aktivitas Dan Kemampuan Menulis Surat Lamaran Pekerjaan Melalui Metode Sibomber Berbantuan Kuis Interaktif pada Peserta Didik Kelas I-4 SMA Negeri 3 Malang 
peningkatan dari siklus I ke siklus II. Pada siklus I, beberapa peserta didik belum memenuhi kriteria ketuntasan minimal (KKM), yakni 70. Kendala yang dihadapi adalah peserta didik kurang mampu memahami ilustrasi pekerjaan yang diberikan oleh pendidik. Ilustrasi pekerjaan yang dijadikan sebagai sumber menulis surat lamaran terdapat petunjuk yang kurang jelas, misalnya beberapa ilustrasi belum mencantumkan alamat surat, pihak yang dituju, dan persyaratan data yang diperlukan. Dalam proses menulis, rata-rata peserta didik yang kurang aktif saat belajar terbimbing mengalami kesulitan dalam menulis surat lamaran pekerjaan secara mandiri. Oleh karena itu, pada siklus I sebanyak 6 peserta didik belum memenuhi KKM sehingga diperoleh ketuntasan klasikal sebesar 70\%. Dengan demikian, perlu dilakukan peningkatan pada siklus II, karena ketuntasan secara klasikal belum mencapai $80 \%$.

Hasil kemampuan menulis surat lamaran pekerjaan pada siklus II mengalami peningkatan yang cukup signifikan. Setelah melakukan perbaikan pembelajaran pada siklus I, dari keseluruhan peserta didik (20 orang) telah memenuhi KKM. Berikut perolehan kemampuan menulis surat lamaran pekerjaan pada siklus I dan siklus II beserta perbandingan dan peningkatannya.

Tabel 5 Perbandingan Hasil Kemampuan Menulis Surat Lamaran Pekerjaan pada Siklus I dan Siklus II

\begin{tabular}{|c|c|c|c|}
\hline \multirow{2}{*}{ No. } & \multirow{2}{*}{ Aspek Pencapaian Hasil Belajar } & \multicolumn{2}{|c|}{ Siklus } \\
\hline & & Siklus I & Siklus II \\
\hline 1. & Siswa yang mendapat nilai $<70$ & 6 peserta didik & 0 peserta didik \\
\hline 2. & Siswa yang mendapat nilai $\geq 70$ & 14 peserta didik & 20 peserta didik \\
\hline & Nilai rata-rata & 77 & 87,8 \\
\hline & Peningkatan nilai rata-rata & \multicolumn{2}{|c|}{10,8} \\
\hline & Ketuntasan klasikal & 70 & 100 \\
\hline & Peningkatan ketuntasan klasikal & \multicolumn{2}{|c|}{30} \\
\hline
\end{tabular}

Data tersebut menunjukkan peningkatan kemampuan menulis surat lamaran pekerjaan peserta didik pada siklus I dan siklus II. Pada siklus I sebanyak 14 peserta didik dinyatakan tuntas dan 6 peserta didik belum tuntas sedangkan pada siklus II keseluruhan peserta didik dalam kelas (20 orang) telah memenuhi KKM. Nilai rata-rata siklus I dengan siklus II mengalami peningkatan. Nilai rata-rata siklus I sebesar 77 menjadi 87,8 pada siklus II sehingga diperoleh peningkatan sebesar 10,8. Ketuntasan klasikalnya pun meningkat dari $70 \%$ pada siklus I menjadi $100 \%$ pada siklus II. Hal ini menunjukkan hasil ketuntasan klasikal tes kemampuan menulis pada siklus II meningkat sebesar $30 \%$.

Keberhasilan kemampuan menulis surat lamaran pekerjaan dapat diketahui melalui perolehan rata-rata skor setiap aspek penilaian menulis pada siklus I dan siklus II. Adapun aspek penilaian menulis pada siklus I dan siklus II yaitu: (1) kesesuaian isi dengan sumber lowongan pekerjaan, (2) sistematika surat lamaran pekerjaan, (3) kesesuaian isi dengan sistematika surat, (4) penggunaan bahasa (efektif dan baku), (5) penggunaan huruf kapital, (6) ejaan dan tanda baca, dan (7) kerapian. Perolehan rata-rata skor setiap aspek penilaian menulis siklus I dan siklus II beserta perbandingan dan peningkatannya dapat dilihat pada tabel berikut. 
Tabel 6 Perbandingan Perolehan Nilai Tiap Aspek pada Siklus I dan Siklus II

\begin{tabular}{clccc}
\hline No. & \multicolumn{1}{c}{ Aspek yang dinilai } & Siklus I & Siklus II & Penigkatan \\
\hline 1. & Kesesuaian isi dengan sumber lowongan pekerjaan & 3,6 & 3,8 & 0,2 \\
\hline 2. & Sistematika & 4 & 4 & 0 \\
\hline 3. & Kesesuaian isi dengan sistematika & 3,25 & 3,55 & 0,3 \\
\hline 4. & Penggunaan bahasa & 5,7 & 6,4 & 0,7 \\
\hline 5. & Penggunaan huruf capital & 4,4 & 5,4 & 1 \\
\hline 6. & Ejaan dan tanda baca & 3,25 & 4,75 & 1.5 \\
\hline 7. & Kerapian & 3,35 & 3,7 & 0,35 \\
\hline & Jumlah & 27,25 & 31,6 & 4,35 \\
\hline
\end{tabular}

Data di atas menunjukkan bahwa perolehan rata-rata kemampuan menulis peserta didik pada siklus I dan siklus II mengalami peningkatan pada setiap aspeknya. Aspek kesesuaian isi dengan sumber lowongan pekerjaan siklus I mencapai nilai rata-rata 3,6 menjadi 3,8 pada siklus II dengan peningkatan sebesar 0,2. Aspek sistematika pada siklus I dan siklus II dicapai peserta didik secara sempurna dengan nilai rata-rata 4. Aspek kesesuaian isi dengan sistematika siklus I mencapai nilai rata-rata 3,25 menjadi 3,55 pada siklus II dengan peningkatan sebesar 0,3. Aspek penggunaan bahasa siklus I mencapai nilai rata-rata 5,7 menjadi 6,4 pada siklus II dengan peningkatan sebesar 0,7. Aspek penggunaan huruf kapital siklus I mencapai nilai rata-rata 4,4 menjadi 5,4 pada siklus II dengan peningkatan sebesar 1. Aspek penggunaan ejaan dan tanda baca siklus I mencapai nilai rata-rata 3,25 menjadi 3,7 pada siklus II dengan peningkatan sebesar 0,35. Aspek kerapian siklus I mencapai nilai rata-rata 3,35 menjadi 3,7 pada siklus II dengan peningkatan 0,35 . Nilai rata-rata keseluruhan aspek pada siklus I sebesar 27,25 menjadi 31,6 pada siklus II sehingga mengalami peningkatan sebesar 4,35.

Berdasarkan uraian di atas, dapat dikemukakan bahwa metode SIBOMBER berbantuan kuis interaktif yang diterapkan di kelas I-4 SMA Negeri 3 Malang dapat meningkatkan aktivitas belajar dan kemampuan menulis surat lamaran pekerjaan siswa. Perubahan aktivitas siswa yang positif pada setiap siklusnya berpengaruh terhadap keberhasilannya mencapai kriteria ketuntasan minimal yang telah ditetapkan. Hal ini sejalan dengan Putra (2007); (Kartikasari (2010); Salamah, (2018) proses belajar dengan metode pembelajaran model TGT (Team Group Tournamen), Deep Dialogue Critical Creative Thingking (DDCCT) cukup efektif dalam kegiatan menulis. Keunggulan penelitian ini bahwa metode SIBOMBER berbantuan kuis interaktif dapat meningkatkan aktivitas belajar dan kemampuan menulis surat lamaran pekerjaan sehingga pengalaman belajar siswa menjadi lebih luas baik secara mandiri ataupun kelompok sebaya. Keberadaan metode SIBOMBER juga memberi variasi dalam peningkatan keterampilan menulis pada umumnya.

\section{SIMPULAN}

Berdasarkan hasil penelitian dan pembahasan dapat disimpulkan sebagai berikut. Penerapan metode SIBOMBER berbantuan kuis interaktif dapat meningkatkan kemampuan menulis surat lamaran pekerjaan pada siswa kelas I-4 SMA Negeri 3 Malang. Hal ini dilakukan dengan memberikan kesempatan kepada semua peserta didik untuk ikut serta menjawab kuis interaktif, memberikan apresiasi positif kepada peserta didik setelah menjawab pertanyaan dengan benar, mengontrol dan membimbing peserta didik dalam

Binti Ngafifatul Maidah, Sugiarti, Basuki Agus Priyana Putra, Peningkatan Aktivitas Dan Kemampuan Menulis Surat Lamaran Pekerjaan Melalui Metode Sibomber Berbantuan Kuis Interaktif pada Peserta Didik Kelas I-4 SMA Negeri 3 Malang 
kelompok untuk mengoptimalkan pemahaman tentang materi yang belum dikuasai, mengubah formasi kelompok untuk beberapa peserta didik yang kurang mampu dan memberikan bimbingan secara langsung. Melalui metode SIBOMBER berbantuan kuis interaktif pada siklus I persentase keterlaksanaan pembelajaran menulis surat lamaran pekerjaan melalui metode sibomber berbantuan kuis interaktif pada siklus 1 sebesar $72,61 \%$ menjadi $86,9 \%$ pada siklus II. Peningkatan yang diperoleh sebesar $14,29 \%$. Selain itu, nilai rata-rata kemampuan menulis surat lamaran pekerjaan peserta didik pada siklus I sebesar 77 menjadi 87,8 pada siklus II. Peningkatan yang diperoleh sebesar 10,8. Ketuntasan klasikal pada siklus I sebesar $70 \%$ dan pada siklus II meningkat menjadi 100\% sehingga mengalami peningkatan sebesar $30 \%$. Dengan demikian, dapat dibuktikan bahwa penerapan metode SIBOMBER berbantuan kuis interaktif dapat meningkatkan kemampuan menulis surat lamaran pekerjaan, keterlaksaanpembelajaran, aktivitas belajar siswa, ketuntasan klasikal siswa kelas I-4 SMA Negeri 3 Malang.

\section{DAFTAR PUSTAKA}

Adiwisastra, M. F. (2015). Perancangan Game Kuis Interaktif Sebagai Multimedia Pembelajaran Drill and Practice Untuk. II(1), 205-211.

Kemendikbud, I. (2016a). Kompetensi Inti dan Kompetensi Dasar Bahasa Indonesia $S M A / M A / S M K / M A K$.

Kemendikbud, I. (2016b). Peraturan pendidikan dan kebudayaan Republik Indonesia. Kemendikbud, Standar Penilaian Pendidikan. https://doi.org/10.1016/j.athoracsur.2009.09.030

Kemendikbud, I. (2016c). Silabus Mata Pelajaran Sekolah Menengah Atas/Madrasah Aliyah/Sekolah Menengah Kejuruan/Madrasah Aliyah Kejuruan (SMA/MA/SMK/MAK). Kementerian Pendidikan dan Kebudayaan.

Lukman. (2018). PENINGKATAN HASIL BELAJAR MENULIS SURAT LAMARAN PEKERJAAN DENGAN MENGGUNAKAN MEDIA POWER POINT. Jurnal Pendidikan Tambusai, 2(2), 325-337. https://doi.org/10.31004/jptam.v2i3.92

Manulu, L. S. dan S. A. (2018). Peningkatan Kemampuan Menulis Surat Lamaran Pekerjaan Menggunakan Metode Pembelajaran STAD bagi Siswa Kelas XII IPA SMA Negeri 14 Medan Tahun Ajaran 2018-2019. Prosiding Seminar Nasional Pendidikan Bahasa Dan Sastra Indonesia.

Salamah, U. (2018). Pembelajaran Menulis Karya Ilmiah Berbasis Deep Dialogue Critical-Creative Thinking (Ddcct). JINoP (Jurnal Inovasi Pembelajaran), 4(1), 90. https://doi.org/10.22219/jinop.v4i1.5718

Sukatman, dkk. (2013). Model Pembelajaran Kreatif (A. Muti'ah (ed.); Cetakan Pe). Gress Publishing.

Suryaman, Maman., Suherli., dan I. (2018). Buku Guru: Bahasa Indonesia untuk SMA/MA/SMK/MAK Kelas XII (M. R. Purnanto, Dwi. (ed.); Ke-2). Kementerian Pendidikan dan Kebudayaan.

Syarif, E. dkk. (2009). Pembelajaran Menulis (Mudini (ed.); p. 43). Pusat Pengembangan dan Pemberdayaan Pendidikan dan Tenaga Kependidikan Bahasa. 